\title{
O turfe em campinas: vida urbana e novas relações com a natureza no final do século XIX
}

\author{
Nara Romero Montenegro (IC) \\ Carmen Lúcia Soares (PQ) - Orientadora
}

\section{Resumo}

O turfe foi uma prática muito presente em várias cidades brasileiras, principalmente, nas últimas décadas do século XIX e começo do século XX. Na cidade de Campinas, aproximadamente em 1870, já ocorriam alguns páreos. Uma década depois, é construído o primeiro hipódromo da cidade localizado no bairro do Bonfim. Esta pesquisa tem como objetivo analisar o contexto do surgimento e do desenvolvimento inicial do turfe na cidade de Campinas, no período aqui referido, com ênfase nas possíveis representações sociais oriundas dessa prática. $\mathrm{O}$ ambiente do hipódromo era aquele no qual uma aristocracia desejava afirmar-se e preservar-se; lá era possível confrontar diversas expressões e sentimentos de classes sociais distintas, onde reconheciam-se mutuamente, em seus lugares bem delimitados e previamente definidos.

Palavras Chave: corrida de cavalo, natureza, vida urbana

\section{Introdução}

O turfe foi uma prática de grande repercussão no final do século XIX em grandes cidades do Brasil. Em Campinas já na segunda metade do século, eram muito comuns as corridas de cavalo (Gazeta de Campinas 1870-1875). Antes da construção do primeiro Hipódromo em 1878, as corridas ocorriam em forma de páreos. Já no início da década de 70, percebe-se um esforço para institucionalizar a prática, liderado pelo Club de Corridas Campineiro, bastante relatado pelos periódicos da época. É, portanto, nesse período de surgimento e crescimento inicial do turfe que esta pesquisa pretende se debruçar. Certas questões emergem para uma melhor reflexão da prática dentro da realidade local no final do século XIX: O que tornou possível a prática do turfe em Campinas? Como se dava o envolvimento das diversas classes sociais com esta prática? Quais eram as simbologias que a permeavam?

\section{Resultados e Discussão}

É em meio a uma recente polarização - rural e urbano -que surgem as corridas de cavalo e, em seguida, o turfe como prática institucionalizada. Melo (1999) em sua tese sobre o surgimento do turfe no Rio de Janeiro, aponta como aspectos determinantes para a emergência do turfe: a influência européia, principalmente através dos imigrantes, a proximidade do cavalo na cultura da época e o firme envolvimento da elite com a prática. Entretanto, refletindo acerca da história de Campinas, os elementos combinados do campo e da cidade contidos tacitamente na prática do turfe é que tornaram possível a sua emergência

Esta pesquisa, de cunho bibliográfico e documental, sustenta-se através de leituras específicas em relação ao turfe e outras, mais abrangentes, que dão um suporte teórico e conceitual na contextualização sociocultural da cidade Campinas e das novas relações com a natureza que se estruturaram no período do final do século XIX. Além da leitura de periódicos do período referido.

\section{Conclusões}

A corrida de cavalos no final século XIX congrega, ao mesmo tempo, uma marca de modernização ligada a um referencial de civilização europeia, e uma relação profunda com a natureza. A legitimação do turfe deve-se, portanto, também a uma polarização frágil e ainda muito borrada entre vida urbana e rural, perceptível no período estudado.

\section{Agradecimentos}

Financiado pela Fundação de Amparo à Pesquisa do estado de São Paulo (FAPESP)

\footnotetext{
${ }^{1}$ Gazeta de Campinas. Campinas, 1870-1875

${ }^{2}$ LAPA, José Roberto do Amaral. A Cidade: Os Cantos e os Antros. Campinas 1860-1900. São Paulo: Edusp, 1996

${ }^{3}$ MELO, Victor Andrade de. Cidade "Sportiva": O Turfe e o Remo no Rio de Janeiro (1849 - 1903). Rio de Janeiro: Universidade Gama Filho, 1999.
} 